University of Michigan Law School

University of Michigan Law School Scholarship Repository

Law \& Economics Working Papers

$1-1-2018$

\title{
The Elephant Always Forgets: Tax Reform and the WTO
}

Reuven S. Avi-Yonah

University of Michigan Law School, aviyonah@umich.edu

Follow this and additional works at: https://repository.law.umich.edu/law_econ_current

Part of the Law and Economics Commons, Public Law and Legal Theory Commons, and the Tax Law Commons

Working Paper Citation

Avi-Yonah, Reuven S., "The Elephant Always Forgets: Tax Reform and the WTO" (2018). Law \& Economics Working Papers. 147.

https://repository.law.umich.edu/law_econ_current/147

This Article is brought to you for free and open access by University of Michigan Law School Scholarship Repository. It has been accepted for inclusion in Law \& Economics Working Papers by an authorized administrator of University of Michigan Law School Scholarship Repository. For more information, please contact mlaw.repository@umich.edu. 


\title{
THE ELEPHANT ALWAYS FORGETS: TAX REFORM AND THE WTO
}

\author{
Reuven S. Avi-Yonah \\ The University of Michigan
}

\begin{abstract}
The "Tax Cuts and Jobs ACT" (TCJA) enacted on December 22, 2017, includes several provisions that raise WTO compliance issues. At least one such provision, the Foreign-Derived Intangible Income (FDII) rule, is almost certain to draw a challenge in the WTO and is likely to lead to another US loss and resulting sanctions. This outcome would be another addition to the repeated losses suffered by the US for export subsidies from the 1970s to 2004, which led to the imposition of sanctions and the ultimate repeal of the offending regime. The important question for 2018 and beyond is whether the Trump administration and its Congressional allies will react to such a loss in a similar fashion as the Bush administration did in 2004, or whether it will defy the WTO, with potential far reaching consequences for the world trade order.
\end{abstract}

\section{Introduction: Tax and Trade}

From the origins of the world trade regime, it has been clear that tax laws can undermine the proper functioning of trade rules in two main ways. First, taxes can serve as tariff barriers if they are imposed on imports but not on domestic sales. Second, remission of taxes on exports can serve as an export subsidy. ${ }^{1}$

The first type of tax measure violates GATT II:1(b) because it is an unscheduled charge on importation that is not an "ordinary customs duty." Alternatively, if the tax is imposed on importers but not on domestic sellers, it can be found to violate GATT III:2 as a discriminatory internal tax.

\footnotetext{
${ }^{1}$ See generally Avi-Yonah and Slemrod, (How) Should Trade Agreements Address Income Tax Issues, 55 Tax L. Rev. 533 (2002); Avi-Yonah, The WTO, Export Subsidies, and Tax Competition, in Michael Lang, Judith Herdin and Ines Hofbauer (eds.), WTO and Direct Taxation 115 (Linde, 2005); Avi-Yonah, Treating Tax Issues Through Trade Regimes, 26 Brooklyn J. Int'l L. 1683 (2001); Avi-Yonah, Tax, Trade, and Harmful Tax Competition: Reflections on the FSC Controversy, 21 Tax Notes Int'l 2841 (Dec. 18, 2000).
} 
The second type of tax measure violates the Subsidies and Countervailing Measures Agreement ("SCM Agreement"), which applies to goods but not to services. Article 1 of the SCM Agreement defines a subsidy as a financial contribution by a government conferring a benefit, which includes: the direct transfers of funds, goods or services (other than infrastructure), and the noncollection or forgiveness of taxes otherwise due. The SCM Agreement distinguishes three categories of subsidies: prohibited subsidies, nonactionable subsidies, and actionable subsidies. The prohibited subsidies category, described in Article 3 of the SCM Agreement, includes:

a. Subsidies that are contingent, in law or in fact, upon export performance, and

b. Subsidies that are contingent upon the use of domestic over imported goods.

These subsidies are prohibited outright and countries are allowed to unilaterally impose countervailing measures against the country that created them.

On the other side of the spectrum, non-actionable subsidies are specific types of subsidies that are allowed by the WTO. The non-actionable subsidies are detailed in article 8 of the SCM Agreement, which includes subsidies for research and assistance activities conducted by higher education and research establishments, certain types of assistance to disadvantaged regions, and certain subsidies for compliance with environmental regulations. Finally, the actionable subsidies category includes any other subsidies that are not considered "prohibited" or "non-actionable" (under articles 3 and 8 of the agreement), and that satisfy the following two additional requirements:

a. Specificity: An actionable subsidy is considered specific when the eligibility to receive the benefits is limited to certain enterprises or industries (article 2 of the SCM Agreement), and

b. Adverse effect: An actionable subsidy is considered adverse when it produces a serious prejudice to the interests of another member, an injury to its domestic industry, or a nullification or impairment of benefits accruing directly or indirectly to other members under the GATT (article 5 of the SCM Agreement).

When an actionable subsidy is specific and produces an adverse effect, the affected countries are entitled to file a formal complaint with the WTO Dispute Settlement Body, and may impose retaliatory sanctions in the event that the complaint is upheld. 
The TCJA includes two measures that potentially violate these rules: The Base Erosion Anti-Abuse Tax, or BEAT (Internal Revenue Code (IRC) section 59A), which can be seen as imposing a hidden tariff, and the Foreign Derived Intangible Income provision, or FDII (IRC section 250), which can be seen as an export subsidy.

\section{The BEAT}

Under new IRC section 59A, US corporate taxpayers have to pay a "base erosion anti-abuse tax" (BEAT), at 10\% less any applicable credits (including the foreign tax credit, but the US taxpayer is unlikely to have them for the relevant income since any foreign tax is imposed on the foreign related party). The tax base is taxable income plus "base erosion payments", defined as any amount paid or accrued by a taxpayer to a foreign person that is a $25 \%$ related party of the taxpayer and with respect to which a deduction is allowable, including interest (to the extent not otherwise disallowed) and, for inverted corporations, also cost of goods sold. The BEAT also applies to imports of depreciable property. Withholding taxes (if any) are allowed as an offset. There is a safe harbor for smaller corporations with gross receipts below $\$ 500$ million and another for base erosion payments of less than $3 \%$ of gross income. The proposal applies to base erosion payments paid or accrued in taxable years beginning after December 31, 2017.

The BEAT was enacted to address concerns about deductible payments to related parties being used to erode the US corporate tax base. This concern originally applied primarily in the context of inversions, because a major reason for inversions was that following the inversion (i.e., making the US parent a subsidiary of new foreign parent) it was possible to load up the US parent with debt, generating deductible interest payments to new foreign parent in a low-tax jurisdiction. But the BEAT is broader than this, applying not only to payments to foreign parents but also to payments to foreign subsidiaries.

The BEAT was enacted in lieu of a much broader House provision that would have applied a $20 \%$ excise tax to all deductible payments to foreign related parties including cost of goods sold. Such a provision would have been a probable violation of the anti-tariff rule of GATT II:1(b) (because it is an unscheduled charge on importation of goods) and of the non-discrimination provision of GATT III:2 (because it only applies to payments to foreign parties).

The BEAT is much narrower, and most of it applies to interest and royalties, which are not covered by GATT. There are two provisions that can potentially violate the GATT rules, but neither of them is likely to occur frequently in practice. The first is the imposition of BEAT on the import of 
depreciable property. Since this does not include inventory or parts (which are not depreciable), it would seem unlikely that it would be imposed frequently enough to warrant a WTO challenge, because the scope of permitted countervailing measures would be quite limited.

The second and potentially more troubling aspect of BEAT is its imposition on cost of goods sold in the context of inversions. This can be quite broad and lead to a WTO violation. However, the provision only applies to post November 2017 inversions that qualify as such under the definitions of IRC section 7874, and no inversion after section 7874 was enacted in 2004 has qualified as such because the 7874 definition is relatively easy to avoid (ad was left unchanged by TCJA). This, it seems unlikely that the BEAT would actually ever apply to cost of goods sold in practice.

\section{The FDII}

TCJA and new IRC sections 951A and 250 provide that a $10.5 \%$ tax will apply to the foreign income of subsidiaries of US multinationals (CFCs) if it exceeds a $10 \%$ rate of return on their tangible assets. Because this rate is lower than the new US corporate rate of $21 \%$ and because there is no longer a tax imposed on dividends from CFCs to their US parents, a concern arose that there will be increased incentive to shift income from the US parents to CFCs in lower tax jurisdictions.

To address the problem of shifting income from the US to CFCs, new IRC section 250 applies a reduced $13.125 \%$ to "foreign derived intangible income" (FDII) which is defined as the amount which bears the same ratio to the corporation's "deemed intangible income" as its "foreign-derived deduction eligible income" bears to its "deduction eligible income."

Deemed intangible income is the excess of a domestic corporation's deduction eligible income (gross income without regard to certain enumerated categories) over its deemed tangible income return $(10 \%$ of its tangible assets).

The "foreign-derived deduction eligible income" is defined as income derived in connection with (1) property that is sold by the taxpayer to any foreign person for a foreign use or (2) services to any foreign person or with respect to foreign property. In other words, this category comprises exports for property and services, including royalties from the licensing of intangibles.

Deduction eligible income is essentially the domestic corporation's modified gross income. So a U.S. company's foreign derived intangible income, which gets the $13.125 \%$ rate, is the amount that bears the same ratio to the deemed intangible income as the U.S. company's exports bear to its modified gross income. 
While services are excluded from the SCM, the FDII provision clearly applies a lower rate (13.125\% instead of $21 \%$ ) to a domestic US corporation's sales of goods to any foreign person for a foreign use. It is likely that importing goods and then re-exporting them without significant modification will qualify for the lower rate. ${ }^{2}$ Moreover, it is clear that exporting goods, modifying them and then importing them to the US qualifies for the lower rate. $^{3}$

FDII clearly involves the non-collection or forgiveness of taxes otherwise due, i.e., a subsidy under the SCM, and the subsidy is likewise clearly contingent in law and in fact upon export performance. Thus, there is little doubt that the FDII provision is prohibited subsidy in violation of the SCM that entitles trading partners to impose sanctions (unilaterally or after receiving approval from the WTO's Dispute Resolution Body).

\section{How Will the US Respond to Another WTO Loss?}

The FDII is just the latest in a long series of US export subsidies that were struck down by the WTO and its predecessor the GATT. The first adverse decision was a GATT panel that declared the US "Domestic International Sales Corporation" (DISC) regime to be a prohibited export subsidy in the 1970s. The DISC regime was then replaced by the "Foreign Sales

\footnotetext{
2 See Michael Schler, Reflections on the Pending Tax Cuts and Jobs Act (Tax Forum no. 686, Dec. 4, 2017). See also Avi-Yonah, Reuven S. and Batchelder, Lily L. and Fleming, J. Clifton and Gamage, David and Glogower, Ari D. and Hemel, Daniel Jacob and Kamin, David and Kane, Mitchell and Kysar, Rebecca M. and Miller, David S. and Shanske, Darien and Shaviro, Daniel and Viswanathan, Manoj, The Games They Will Play: Tax Games, Roadblocks, and Glitches Under the New Legislation (December 7, 2017). Available at SSRN: https://ssrn.com/abstract=3084187 or http://dx.doi.org/10.2139/ssrn.3084187 and Avi-Yonah, Reuven S. and Batchelder, Lily L. and Fleming, J. Clifton and Gamage, David and Glogower, Ari D. and Hemel, Daniel Jacob and Kamin, David and Kane, Mitchell and Kysar, Rebecca M. and Miller, David S. and Shanske, Darien and Shaviro, Daniel and Viswanathan, Manoj, The Games They Will Play: An Update on the Conference Committee Tax Bill (December 18, 2017). Available at SSRN: https://ssrn.com/abstract=3089423.

${ }^{3}$ See Conference Report, fn. 1522: "If property is sold by a taxpayer to a person who is not a U.S. person, and after such sale the property is subject to manufacture, assembly, or other processing (including the incorporation of such property, as a component, into a second product by means of production, manufacture, or assembly) outside the United States by such person, then the property is for a foreign use." http://docs.house.gov/billsthisweek/20171218/Joint\%20Explanatory\%20Stateme nt.pdf.
} 
Corporation" (FSC) regime that was declared by the WTO's DSB and Appellate Body to be a prohibited export subsidy in the late 1990s. FSC was in turn replaced by the "Extraterritorial Income" (ETI) regime, which was in turn declared to be a prohibited export subsidy in 2004. This led the GOPcontrolled Congress and the Bush administration to repeal the ETI and replace it with a domestic manufacturing provision (IRC section 199) that did not violate the SCM because it was not contingent on export performance.

This history was well known to the drafters of TCJA. In fact, the FDII provision is a direct descendant of the "border adjusted tax" (BTA) that was proposed by the House Republicans in 2016 and that was broadly declared to be a violation of the SCM. ${ }^{4}$ Nevertheless, the drafters of TCJA decided to repeal IRC section 199 (which did not violate the SCM) and replace it with the FDII, which (unlike, for example, the ETI) is a blatant and obvious violation of the SCM. ${ }^{5}$

This raises the question of whether the current administration and the Republican majorities in Congress would react to another WTO loss and sanctions in the same way as the Bush Administration and its GOP Congressional majorities reacted in 2004 , i.e., by repealing the offensive provision. I believe the answer is probably no. Here is the reply to this question provided by a senior GOP lobbyist:

"Top USTR staff told me in March 2017 that the WTO will likely, one day, take on the Trump administration. The implication was that the future of the WTO would be at risk because the economic nationalists are WTO skeptics... Sovereignty is a big issue for the administration. It is also big among lefty fair traders. The WTO should not be able to overrule US laws.

Tax is something the GOP free traders care deeply about. If a country took us on at the WTO, the GOP opposition to the WTO would grow. If the WTO rules against us, the remedy is to authorize tariffs by the petitioner against US goods or services of the petitioner's choice. The WTO does not directly change domestic US law after a ruling. The US could simply pay those tariffs as it has in one or two cases in the past.

Or the US could increase its challenge to the WTO in ways that USTR Bob Lighthizer would likely be creative about. In addition to what he

\footnotetext{
${ }^{4}$ See Avi-Yonah and Clausing, Problems with Destination-Based Corporate Taxes and the Ryan Blueprint, 8 Columbia J. Tax L. 229 (2017).

5 This issue was raised by Rebecca Kysar well before TCJA was enacted. See Rebecca Kysar, The Senate Tax Plan Has WTO Problems, Medium.com (Nov. 12, 2017), https://medium.com/whatever-source-derived/the-senate-tax-plan-has-a-wtoproblem-guest-post-by-rebecca-kysar-31deee86eb99.
} 
is doing now... (1) preventing the re-authorization of the term of a WTO judge on grounds that he rules on the basis of doctrine not contained in the WTO agreement, or (2) preventing the WTO negotiation functions from achieving new agreements.

The National Security Strategy released by the administration last Monday basically said that liberalizing trade with China was a mistake because the assumption that China would be more democratic and capitalistic ended up wrong. Lighthizer has said that the WTO is illequipped to handle comprehensive state-capitalism, and ill-equipped to handle the varying economic systems and development levels of all its members.

This is a long way of saying - I'm not sure. But any WTO challenge could threaten the existence or efficacy of the WTO because of this context. Or threaten the US willingness to continue as a member. As between tax cuts and the WTO, the GOP free traders would likely choose tax cuts."

\section{Conclusion}

If the GOP lobbyist is to be believed, a WTO challenge to the FDII could result in a major clash between the US and the WTO, with potentially disastrous consequences. Even if he is exaggerating, the willingness of the GOP Congressional majorities to defy the WTO stands in stark opposition to the way the GOP behaved in 2004. This relatively obscure tax issue could have very troubling long-term implications. 